\title{
Stem conduction systems effect on the production and quality of mini tomato under organic management
}

Joara Secchi Candian ${ }^{1 \star}$, Bruno Novaes Menezes Martins ${ }^{1}$ Antonio Ismael Inácio Cardoso", Regina Marta Evangelista ${ }^{1}$, Erika Fujita ${ }^{2}$

1. Universidade Estadual Paulista “Júlio de Mesquita Filho" - Departamento de Horticultura - Botucatu (SP), Brazil.

2. Universidade Federal de Roraima - Boa Vista (RR), Brazil.

ABSTRACT: This research evaluated the influence of stem conduction types on the production and physicochemical characteristics of tomato fruits (hybrid Coco, mini type) under organic management. The experiment was conducted between August 2013 and January 2014. The treatments consisted of 4 different conduction systems: 2 traditional stems; 2 stems emerging from axillary cotyledon buds ("bottom stem"); 3 "traditional" stems and 4 stems emerging from tip pruning. Eleven harvests were conducted from $22^{\text {nd }}$ November 2013 to $31^{\text {st }}$ January 2014. Data collected included fruit number per plant, yields (g.plant ${ }^{-1}$ ), fruit physicochemical characteristics, average weight, fruit diameter, $\mathrm{pH}$, titratable acidity (TA), soluble solids (SS), SS/TA ratio, reducing sugars, ascorbic acid, lycopene, $\beta$-carotene, chlorophyll- $a$ and chlorophyll- $b$. Stem conduction types did not affect fruit yields per plant (g.plant $\left.{ }^{-1}\right)$. However, the greater number of stems resulted in more fruits per plant, but the fruit produced had a smaller diameter and average weight. The treatments with more stems also showed higher fruit lycopene levels, TA, and reducing sugars. Thus, under similar growing conditions, it may be recommended that organic mini tomatoes be pruned with 3 or 4 stems to increase the number of fruits per plant.

Key words: Solanum lycopersicum L., "bottom stem", tip pruning, physicochemical characteristics. 


\section{INTRODUCTION}

Organic food is still consumed by a small portion of the population, but it has been gaining ground in the consumer market. Research shows that consumers cite health concerns as the main motivation to consume organic food, and the absence of pesticides is mentioned as the most important attribute of these foods (Willer 2010).

Tomato (Solanum lycopersicum L.) is one of the most valued vegetable crops by organic consumers (Feng et al. 2011). Among tomatoes varieties, the mini tomato is by far the most valued in Brazil (Takahashi and Cardoso 2015). There is little research on how to manage prunning and sprout thinning in this system, mainly, because mini tomatoes can respond differently than cultivars with larger fruits. Some studies have shown the consequences of removing the terminal bud, e.g. it reduces plant height, facilitates staking to increase cultivation efficiency, and improves the distribution of solar radiation in the canopy (Camargos et al. 2000). Pruning can also affect the fruit physicochemical characteristics, which are also fruit quality indicators, e.g. titratable acidity (TA), soluble solids (SS) and SS/TA. As for sprout thinning, the greater the number of stems per plant, the greater the yields. However, fruits become smaller (Marim et al. 2005; Charlo et al. 2009).

Despite the popularity of tomatoes, there is little information about the relationship between stem numbers and fruit production of mini tomatoes grown under organic management. This research aimed to evaluate the effect of stem conduction types on the production and quality of mini tomato under organic management.

\section{MATERIAL AND METHODS}

The experiment was carried out between August 2013 and January 2014 in São Manuel, São Paulo State (lat $22^{\circ} 46^{\prime}$ S, long $48^{\circ} 34^{\prime} \mathrm{W}$, and altitude of $740 \mathrm{~m}$ ). The predominant climate of the region, according to Köppen climate classification, based on meteorological observations, is $\mathrm{Cfa}$ (humid subtropical, mesothermal) (Cunha and Martins 2009). During the experiment, maximum and minimum temperature was recorded with a thermometer installed at the center of the greenhouse at $1.5 \mathrm{~m}$ from the ground. Readings were performed daily at 7:30 a.m.
The plants were conducted in an arch-type greenhouse (2.5 m height $\times 7 \mathrm{~m}$ width $\times 20 \mathrm{~m}$ length), covered with low-density polyethylene (150 $\mu \mathrm{m}$ thick); the sides were closed with an anti-aphid screen.

The soil used is an Oxy Soil Typical, with the following results obtained from chemical analysis prior to the experiment initiation: $\mathrm{pH}_{(\mathrm{CaCl} 2)}=6.6 ; \mathrm{P}_{\text {resin }}=77 \mathrm{mg} \cdot \mathrm{dm}^{-3}$; organic matter $=15 \mathrm{~g} \cdot \mathrm{dm}^{-3} ; \mathrm{V} \%=88 ; \mathrm{H}+\mathrm{Al}=11 \mathrm{mmol}_{\mathrm{c}} \cdot \mathrm{dm}^{-3}$; $\mathrm{K}=3.0 \mathrm{mmol}_{c} \cdot \mathrm{dm}^{-3} ; \mathrm{Ca}=52 \mathrm{mmol}_{c} \cdot \mathrm{dm}^{-3} ; \mathrm{Mg}=30 \mathrm{mmol}_{c} \cdot \mathrm{dm}^{-3}$; $\mathrm{SB}=95 \mathrm{mmol} \cdot \mathrm{dm}^{-3}$ and $\mathrm{CTC}=83 \mathrm{mmol} \cdot \mathrm{dm}^{-3}$.

At planting fertilizer was applied at a rate of $0.5 \mathrm{~kg} \cdot \mathrm{m}^{-2}$ organic compost (Provaso ${ }^{\circledR}$ : $\mathrm{pH}=7.0 ; \mathrm{C} / \mathrm{N}=16 / 1$; $\mathrm{Na}=718 \mathrm{mg} \cdot \mathrm{kg}^{-1} ; \mathrm{Cu}=63 \mathrm{mg} \cdot \mathrm{kg}^{-1} ; \mathrm{Fe}=7,383 \mathrm{mg} \cdot \mathrm{kg}^{-1}$; $\mathrm{Mn}=236 \mathrm{mg} \cdot \mathrm{kg}^{-1} ; \mathrm{Zn}=150 \mathrm{mg} \cdot \mathrm{kg}^{-1}$ and the values of $\mathrm{N} ; \mathrm{P}_{2} \mathrm{O}_{5}, \mathrm{~K}_{2} \mathrm{O}$; Ca; Mg; S; U-65 ${ }^{\circ} \mathrm{C}$; organic matter and total carbon, expressed in percentage, respectively: $0.5 ; 0.6 ; 0.4 ; 1.4 ; 0.2 ; 0.2 ; 31 ; 15$ and 8$)$. Throughout the experiment, top dressing fertilization was performed 4 times, on the following days: 15; 28; 37 and 43 days after transplanting (DAT). Biofertilizers were applied through the fertigation system, using both castor bean cake and Bokashi (250 mL.plant ${ }^{-1}$.application $\left.{ }^{-1}\right)$, which began when fruits first started to appear. The biofertilizers was prepared by fermenting castor bean cake and Bokashi. The nutrient solution consisted of $30 \mathrm{~L}$ of castor bean cake and $10 \mathrm{~L}$ of Bokashi for $75 \mathrm{~L}$ of water. The solution was fermented for 2 weeks in a capped plastic tank, placed in the shade, and, from there, it was used for fertigation. Irrigation was carried out daily by drip tubes, by emitter with $0.5 \mathrm{~m}$ of spacing.

The treatments consisted of 4 different conduction systems: 2 traditional stems (main and secondary stems below the first inflorescence); 2 stems with a "bottom stem" (derived from axillary buds of the cotyledons), due to pruning of the apical plant meristem just above the cotyledons with the seedlings still in the tray; 3 "traditional" stems (main stem and 2 -side stems below the first and second inflorescences); and 4 stems with a "bottom stem", with 2 of them derived from the "bottom stem", and the 2 others with the stems below the first inflorescence in each initial stem. The experimental design consisted of completely randomized blocks, with 5 replications. The plots contained 6 plants, with 4 inside the row used for data collection.

The cultivar used was mini tomato hybrid Coco (Takii Seeds). On $26^{\text {th }}$ August 2013, sowing was performed in polypropylene trays with 162 cells, containing substrate for vegetables. On $25^{\text {th }}$ September 2013, the seedlings 
were transplanted with a spacing of $1.0 \mathrm{~m} \times 0.5 \mathrm{~m}$. Staking was carried out with 1 bamboo stake for each stem. Buds that were not part of the treatments were removed. After flowering, the plants were manually vibrated daily to encourage self-pollination, according to Higuti et al. (2010). The experiment was conducted under organic management, following the recommendations by Souza and Resende (2014) to control pests and diseases. There was a small attack of Oidiopsis haplophylli (Leveilula taurica), which was controlled with the use of raw milk $20 \%$. As the leaves got older, they were removed from the bottom of the plants.

From $22^{\text {nd }}$ November 2013 to $31^{\text {st }}$ January 2014, 11 harvests were performed. The fruits were harvested weekly when they were completely red. Fruit quality and productivity data were collected from all the fruits of 4 plants per plot. Data collected included: marketable fruit yield per plant (number and g.plant ${ }^{-1}$ ), fruit diameter $(\mathrm{mm})$, and average fruit weight $(\mathrm{g})$. Defective fruits were not observed. In a sample of 10 fruits per plot on each harvest, the following characteristics were evaluated: SS ( $\left.{ }^{\circ} \mathrm{Brix}\right) ; \mathrm{pH}$; TA (\% citric acid in $100 \mathrm{~g}$ of pulp), according to the methodology described by the Brazilian Ministry of Health (MS 2005); ascorbic acid (mg ascorbic acid per $100 \mathrm{~g}$ of pulp) according to the Brazilian Ministry of Agriculture, Livestock and Food Supply (MAPA 2007); reducing sugars content (\%), according to Somogyi and adapted by Nelson (1944); and SS/TA. Lycopene, $\beta$-carotene, chlorophyll- $a$ and chlorophyll- $b$ (mg. $\left.100 \mathrm{~g}^{-1}\right)$ were determined as described by Nagata and Yamashita (1992).

The data was subjected to analysis of variance, and multiple comparisons were assessed by Tukey's test $(\mathrm{p}<0.05)$. All data analyses were done using the Sisvar software (Ferreira 2011). A simple correlation analysis was conducted among all variables.

\section{RESULTS AND DISCUSSION}

The early flowering of all plants occurred about 25 DAT (20 $0^{\text {th }}$ October 2013) and lasted until early January 2014. During this period, the average daily temperature inside the greenhouse varied from 17.5 to $33^{\circ} \mathrm{C}$. According to Keillor (2008), the maximum temperatures were above the optimum range for fruiting, from 18.5 to $26.5^{\circ} \mathrm{C}$. If we consider the average maximum temperature $\left(37^{\circ} \mathrm{C}\right)$, some production loss must have occurred, i.e. flowers abortion, which is normally observed under these conditions.

Conduction type and stem number did not influence the total yield (g) per plant (Table 1). These results differ from those found by Takahashi and Cardoso (2015), who observed that mini tomato grafted plants with 2 stems and their apical meristem pruned at the time of seedling ("bottom stem") had greater yields than control, unpruned plants due to the higher number of inflorescences. However, these authors studied grafted plants of another hybrid ('Sweet Grape'). Furthermore, in their research, the seedlings of plants with either tip pruning or traditional culture showed similar development in the field (Takahashi and Cardoso 2015). Conversely, in the present research, tip pruning impaired initial plant development, which was probably due to the stress caused by early pruning, which consequently delayed shoot growth in the axils of the cotyledons.

Although not statistically significant, a trend was observed for increased production of plants with 3 stems. Furthermore, plants with more stems ( 3 and 4 ) produced more fruits than those with 2 stems with tip pruning (Table 1). Marim et al. (2005) and Charlo et al. (2009) also reported a greater number of fruits on plants of tomato (Santa Cruz type) with 2 stems compared to plants with only 1 stem.

Table 1. Total production per plant, total fruit number per plant, fruit diameter, and average fruit weight as affected by the type of stem pruning in mini tomato plants.

\begin{tabular}{|c|c|c|c|c|}
\hline Treatments & TPP (g·plant $\left.{ }^{-1}\right)$ & TFNP & FD $(\mathrm{mm})$ & AFW (g·fruit $\left.{ }^{-1}\right)$ \\
\hline 2 traditional stems & $3,886.42 \mathrm{a}$ & $251.75 \mathrm{ab}$ & $33.31 \mathrm{a}$ & $15.47 a$ \\
\hline 2 stems from "bottom stem" & $3,528.24 a$ & $220.25 b$ & $32.90 \mathrm{ab}$ & $16.10 \mathrm{a}$ \\
\hline 3 traditional stems & $4,049.15 a$ & $294.50 \mathrm{a}$ & $32.10 \mathrm{bc}$ & $13.84 \mathrm{~b}$ \\
\hline 4 stems from "bottom stem" & $3,687.25 \mathrm{a}$ & $290.30 \mathrm{a}$ & $31.06 \mathrm{c}$ & $12.76 \mathrm{~b}$ \\
\hline CV (\%) & 10.35 & 12.09 & 1.90 & 5.40 \\
\hline $\mathrm{F}$ & $1.68^{\text {ns }}$ & $6.01^{*}$ & $13.01^{* *}$ & $18.79^{* *}$ \\
\hline
\end{tabular}

$\star \star \star *$, nsSignificant at $1 \%$ probability level $(p<0.01)$, significant at $5 \%$ probability $(0.01 \leq p<0.05)$, and non-significant ( $p \geq 0.05)$ by the F-test, respectively. Numbers followed by the same letter within each column are significantly equivalent according to Tukey's multiple comparison test $(p<0.05)$. TPP $=$ Total production per plant; TFNP = Total fruit number per plant; FD = Fruit diameter; AFW = Average fruit weight; $C V=$ Coefficient of variation . 
Although the plants with 3 and 4 stems had higher fruit numbers per plant, they also had smaller diameter and average weight as compared to plants with 2 stems (Table 1 ). Regarding average fruit weight, plants with 3 or 4 stems had more inflorescences and more fruits produced, which resulted in lower average fruit weights as compared to plants with less stems. The greater number of productive inflorescences may have caused competition for the plant photoassimilates, causing a reduction in fruit diameter and average weight. Mueller and Wamser (2009) also reported that an increase in the number of fruits caused a decrease in the average fruit weight. Reduction in fruit diameter was also observed by Marim et al. (2005) when they increased the number of stems per plant. Carvalho and Tessarioli Neto (2005) also reported that plants with 2 stems had an increase in the number of fruits per plant than those with a single stem, but with a lower average weight.

Evaluating the hybrids Salada Longa Vida and Santa Cruz, with 1 or 2 stems, Matos et al. (2012) obtained the highest average fruit weight in plants with only 1 stem. Charlo et al. (2009) found average weight of 110 and $96 \mathrm{~g}$ per fruit for 1 and 2 stems conduction, respectively. Takahashi and Cardoso (2015) also observed a decrease in weight and average diameter of fruits of mini tomatoes 'Sweet Grape' in relation to the greater number of fruits produced per plant.

Statistically, there were no significant differences between treatments with respect to yields (g.plant ${ }^{-1}$ ), with statistical ones only found with respect to fruit number per plant. However, a trend was observed for increased production in the plants with 3 stems. Moreover, the 3-stem pruning system resulted in more vigorous plants, with desirable fruit size, good quality. The 3 -stem plants were easier to prune than the plants with 4 stems.

The treatments did not affect the concentrations of chlorophyll- $a$ and chlorophyll- $b, \beta$-carotene, SS, SS/TA, $\mathrm{pH}$, and ascorbic acid (Table 2). In fruits, chlorophyll- $a$ and chlorophyll- $b$ showed pulp values of 29.58 and $34.93 \mu \mathrm{g} \cdot 100 \mathrm{~g}^{-1}$, respectively. Santos Júnior et al. (2005) found total chlorophyll values ranging from 480 to $790 \mu \mathrm{g} \cdot 100 \mathrm{~g}^{-1}$ of pulp. The difference found by these authors is due to the influence of various factors that can work together or separately in the decomposition of chlorophyll, such as genotype (cultivars), management, internal conditions of the fruit, harvest time, and methodology evaluation. The main reason for these differences may be related to the fruit color. In this study, the analyzed fruits were completely red, while

Table 2. Mean content of chlorophyll- $a$, chlorophyll- $b$, lycopene, $\beta$-carotene, titratable acidity, soluble solids, SS/TA ratio, $\mathrm{pH}$, reducing sugars, and ascorbic acid as affected by different stem pruning conduction systems in mini tomato plants.

\begin{tabular}{|c|c|c|c|c|c|}
\hline Treatments & $\begin{array}{c}\text { Chlorophyll-a } \\
\text { ( } \mu \mathrm{g} \cdot \mathbf{1 0 0} \mathrm{g}^{-1} \text { pulp) }\end{array}$ & $\begin{array}{c}\text { Chlorophyll-b } \\
\text { ( } \mu \mathrm{g} \cdot 100 \mathrm{~g}^{-1} \text { pulp) }\end{array}$ & $\begin{array}{c}\text { Lycopene } \\
\text { ( } \mu \mathrm{g} \cdot 100 \mathrm{~g}^{-1} \text { pulp) }\end{array}$ & $\begin{array}{c}\beta \text {-carotene } \\
\left(\mu \mathrm{g} \cdot \mathbf{1 0 0} \mathrm{g}^{-1} \text { pulp) }\right.\end{array}$ & $\begin{array}{l}\text { TA } \\
\text { (\% citric acid·100 } \mathrm{g}^{-1} \text { pulp) }\end{array}$ \\
\hline 2 traditional stems & $23.89 a$ & $32.20 \mathrm{a}$ & $15.53 \mathrm{~b}$ & 107.96 a & $0.36 \mathrm{~b}$ \\
\hline $\begin{array}{l}2 \text { stems of "bottom } \\
\text { stem" }\end{array}$ & $28.25 a$ & $28.17 a$ & $19.59 \mathrm{a}$ & 118.89 a & $0.39 a b$ \\
\hline 3 traditional stems & $34.20 \mathrm{a}$ & $51.65 a$ & $20.29 a$ & $108.05 a$ & $0.39 a b$ \\
\hline $\begin{array}{l}4 \text { stems of "bottom } \\
\text { stem" }\end{array}$ & $32.01 \mathrm{a}$ & $27.70 \mathrm{a}$ & 18.17 a & $105.07 \mathrm{a}$ & $0.40 \mathrm{a}$ \\
\hline $\mathrm{F}$ & $1.15^{\text {ns }}$ & $1.21^{\text {ns }}$ & $14.68^{* *}$ & $1.78^{\text {ns }}$ & $4.90^{*}$ \\
\hline $\mathrm{CV}(\%)$ & 31.89 & 68.51 & 6.67 & 9.27 & 4.33 \\
\hline Treatments & SS ( ${ }^{\circ}$ Brix $)$ & SS/TA & pH & RS (\%) & $\begin{array}{c}\text { AA } \\
\left.\text { (mg ascorbic acid } \cdot 100 \mathrm{~g}^{-1} \mathrm{pulp}\right)\end{array}$ \\
\hline 2 traditional stems & $7.27 \mathrm{a}$ & $20.51 a$ & $4.22 \mathrm{a}$ & $4.96 \mathrm{~b}$ & $35.74 a$ \\
\hline $\begin{array}{l}2 \text { stems of "bottom } \\
\text { stem" }\end{array}$ & $7.29 \mathrm{a}$ & $19.00 \mathrm{a}$ & $4.22 \mathrm{a}$ & $4.87 b$ & $34.96 a$ \\
\hline 3 traditional stems & $7.56 \mathrm{a}$ & $19.68 \mathrm{a}$ & $4.22 \mathrm{a}$ & $5.11 \mathrm{ab}$ & $35.40 \mathrm{a}$ \\
\hline $\begin{array}{l}4 \text { stems of "bottom } \\
\text { stem" }\end{array}$ & $7.39 \mathrm{a}$ & $20.60 \mathrm{a}$ & $4.24 a$ & $5.41 a$ & $37.01 \mathrm{a}$ \\
\hline $\mathrm{F}$ & $1.68^{\text {ns }}$ & $3.06^{\text {ns }}$ & $0.92^{\text {ns }}$ & $7.32^{* *}$ & $2.42^{\text {ns }}$ \\
\hline $\mathrm{CV}(\%)$ & 3.07 & 4.84 & 0.40 & 3.84 & 3.54 \\
\hline
\end{tabular}

${ }^{\star \star},{ }^{*}$, nsSignificant at $1 \%$ probability level $(p<0.01)$, significant at $5 \%$ probability $(0.01 \leq p<0.05)$, and non-significant ( $\left.p \geq 0.05\right)$ by the $F$-test, respectively. Numbers followed by the same letter within each column are significantly equivalent according to Tukey's multiple comparison test $(p<0.05)$. TA $=$ Titratable acidity; $\mathrm{CV}=$ Coefficient of variation; $\mathrm{SS}=$ Soluble solids; $\mathrm{RS}=$ Reducing sugars; $\mathrm{AA}=$ Ascorbic acid. 
the fruits evaluated by these authors had some green parts, i.e. containing more chlorophyll.

It was observed that the treatment with 2 traditional stems showed the least amount of lycopene $\left(15.53 \mu \mathrm{g} \cdot 100 \mathrm{~g}^{-1}\right.$ of pulp) (Table 2); $\beta$-carotene showed no differences between the stem number and conduction type, averaging $110 \mu \mathrm{g} \cdot 100 \mathrm{~g}^{-1}$ of pulp. Carotenoids, such as lycopene, are synthesized during ripening with the chlorophyll degradation process. In tomato, the pigment crystals are deposited in the chromoplasts, which can be distributed along the harvests (Seymour et al. 1993). According to Wien (1997), carotenoids production, such as lycopene and $\beta$-carotene, is influenced by light exposure. The traditional 2 -stem treatment system that resulted in plants with less branches with leaves, and, consequently, with less self-shadowing, also showed the lowest lycopene concentration fruit. Silva et al. (2011) evaluated tomato genotype for industry and observed values ranging from 134 to $167 \mu \mathrm{g} \cdot 100 \mathrm{~g}^{-1}$ of pulp, and 244 to $369 \mu \mathrm{g} \cdot 100 \mathrm{~g}^{-1}$ of pulp for lycopene and $\beta$-carotene, respectively. Santos Júnior et al. (2005) found values that ranged from 166 to $430 \mathrm{mg}$ of lycopene. $100 \mathrm{~g}^{-1}$ and 66 to $84 \mathrm{mg} \cdot 100 \mathrm{~g} \mathrm{~g}^{-1}$ of $\beta$-carotene in 10 different genotype samples of tomato. Such results demonstrate that the levels of these pigments can vary significantly depending on the material used, handling, and on the harvest maturity stage of the fruit.

The fruits of plants with 4 stems showed a higher percentage of reducing sugars than the fruits of plants with 2 traditional stems with tip pruning (Table 2). The increase in the plant canopy density, in this case, caused by the increase in the number of stems, also likely increased the competition for photoassimilates, nutrients, light, and water. The reducing sugar values ranged from 4.87 to $5.41 \%$, which are higher than the ones reported by Casa and Evangelista (2009), who reported values from 1.23 to $1.42 \%$, while Ferreira et al. (2010) found values from 1.8 to $2.7 \%$. These values may have been lower than those found in this study because they dealt with different genotypes. In addition to the larger fruits, in their research, the fruits were not picked fully ripened, so their reducing sugar levels might have been lower, as the ripening stage is related to the breakdown of starch into sugars (Ferreira et al. 2010).

No significant differences were observed with respect to SS, with an obtained average value of $7.4^{\circ}$ Brix (Table 2), that was higher and similar to that found by Abrahão et al. (2014) for the hybrids Sweet Million (7.4) and Sweet Grape (7.1).
Takahashi and Cardoso (2015) also reported 7.1 ${ }^{\circ}$ Brix for the 'Sweet Grape' mini tomatoes.

The SS/TA ratio was not affected by the pruning treatments, with an average of 19.94 (Table 2), showing a similar trend of non-significance as the individual SS and TA variables.

There was no significant difference between treatments in $\mathrm{pH}$ values, with an average of 4.22 (Table 2). However, these values are in the same range found by Fontes et al. (2004), who reported an average of 4.00 in 'Carmen' tomato fruits.

Ascorbic acid content was not affected by the treatments (Table 2), with an overall average of $35.77 \mathrm{mg}$ of ascorbic acid $100 \mathrm{~g}^{-1}$ of pulp. Bernardi et al. (2007) reported, when producing in a protected environment, that the amount of ascorbic acid varied from 7 to $23 \mathrm{mg}$ ascorbic acid $100 \mathrm{~g}^{-1}$ of pulp; these values are thus lower than the ones observed in this study.

There was a significant and positive relationship between fruit number and total yield per plant (Table 3). However, these production characteristics did not correlate with the measured fruit physicochemical characteristics ( $\mathrm{pH}, \mathrm{SS}$, $\mathrm{TA}$, and ascorbic acid). A negative correlation was obtained between average weight and number of fruits (Table 3). On the other hand, a positive correlation was obtained between diameter and average fruit weight. Therefore, with the greater number of flowers and fruit produced, the plants likely allocated resources among the several carbohydrate sinks thereby increasing competition between them and reducing the average fruit weight.

Regarding physicochemical characteristics, a negative correlation was observed between average weight and fruit diameter in relation to reducing sugars and SS content (Table 3). This is because smaller fruits tend to have less water, resulting in a greater concentration of solids (Seymour et al. 1993). Fruit diameter also was negatively correlated with the amount of ascorbic acid. There was a significant positive correlation between the percentage of reducing sugars and SS, ascorbic acid, and the SS/TA ratio (Table 3), as sugars and organic acids are the main SS present in food (Chitarra and Chitarra 2005).

Chlorophyll- $a$ was positively correlated with chlorophyll- $b$ and $\mathrm{TA}$, but negatively correlated with $\mathrm{pH}$ (Table 3 ). In turn, chlorophyll- $b$ was negatively correlated with the amount of $\beta$-carotene, which had a positive correlation with lycopene (Table 3). This negative correlation was observed by Wills et al. (1982), who showed that more chlorophyll in the plant lowered the "red coloring" or $\beta$-carotene fruit levels. The $\mathrm{pH}$ is directly 
Table 3. Correlation analysis between reducing sugars levels, chlorophyll- $a$, chlorophyll- $b$, lycopene, $\beta$-carotene, fruit diameter, total yield per plant, total fruit number per plant, average fruit weight, $\mathrm{pH}$, soluble solids, titratable acidity, ascorbic acid, and SS/TA ratio.

\begin{tabular}{|c|c|c|c|c|c|c|c|c|c|c|c|c|c|}
\hline & Chlorophy & lorophy & Lycopene & $\beta$-carotene & FD & TYPP & TFNP & AFW & pH & SS & TA & AA & SS/TA \\
\hline AR & 0.242 & 0.134 & 0.363 & 0.018 & $-0,748^{\star \star}$ & $-0,159$ & 0.214 & $-0,682^{\star \star}$ & -0.225 & $0.756^{\star \star}$ & 0.124 & $0.599^{* *}$ & $0.446^{*}$ \\
\hline Chlorophyll- $a$ & & $0.668^{* *}$ & 0.258 & -0.309 & -0.139 & 0.221 & 0.277 & -0.226 & $-0.431^{*}$ & 0.390 & $0.566^{* *}$ & -0.082 & -0.297 \\
\hline Chlorophyll-b & & & -0.266 & $-0.727^{* *}$ & 0.121 & -0.187 & -0.283 & 0.240 & -0.435 & 0.112 & 0.182 & 0.059 & -0.094 \\
\hline Lycopene & & & & $0.679^{* *}$ & -0.398 & 0.153 & 0.383 & $-0.525^{\star}$ & 0.228 & 0.375 & 0.447 & 0.052 & -0.194 \\
\hline $\boldsymbol{\beta}$-carotene & & & & & -0.197 & 0.136 & 0.270 & -0.319 & 0.309 & -0.003 & 0.065 & 0.079 & -0.077 \\
\hline FD & & & & & & 0.284 & -0.175 & $0.813^{* *}$ & 0.148 & $-0.842^{* \star}$ & -0.376 & $-0.542^{*}$ & -0.240 \\
\hline TYPP & & & & & & & $0.876^{* \star}$ & -0.199 & 0.069 & -0.215 & 0.104 & -0.417 & -0.277 \\
\hline TFNP & & & & & & & & $-0.634^{* *}$ & 0.006 & 0.200 & 0.291 & -0.155 & -0.162 \\
\hline AFW & & & & & & & & & 0.051 & $-0.747^{\star \star}$ & -0.432 & -0.350 & -0.094 \\
\hline pH & & & & & & & & & & -0.238 & -0.134 & -0.183 & -0.030 \\
\hline SS & & & & & & & & & & & $0.459^{*}$ & $0.475^{\star}$ & 0.274 \\
\hline TA & & & & & & & & & & & & -0.165 & $-0.725^{\circ}$ \\
\hline AA & & & & & & & & & & & & & $0.544^{*}$ \\
\hline
\end{tabular}

**, * ns Significant at $1 \%$ probability level $(p<0.01)$, significant at $5 \%$ probability $(0.01 \leq p<0.05)$, and non-significant $(p \geq 0.05)$ by the F-test, respectively. FD = Fruit diameter; TYPP = Total yield per plant; TFNP = Total fruit number per plant; AFW = Average fruit weight; $\mathrm{SS}=\mathrm{Soluble}$ solids; TA = Titratable acidity; $\mathrm{AA}=$ Ascorbic acid.

related to the degradation of the chlorophyll molecule, as it interferes with the functioning of the enzyme chlorophyllase (Wills et al. 1982). Regarding the relationship between lycopene and $\beta$-carotene, Seymour et al. (1993) explain that carotenoids tend to increase with fruit ripening and as chlorophyll is degraded.

There was a positive correlation between SS, TA, and ascorbic acid levels concentration (Table 3). However, the SS/TA ratio showed a significant positive correlation with ascorbic acid and a negative correlation with TA, which was expected because this ratio measures the relationship between SS and TA. Wills et al. (1982) also found a positive correlation between SS and the amount of ascorbic acid in tomato fruits.

Hanson et al. (2004) also found that ascorbic acid had a positive correlation with SS. Furthermore, they also observed a positive correlation between $\beta$-carotene and ascorbic acid, lycopene, and SS levels, which were higher in fruits with a smaller diameter.

\section{CONCLUSION}

The number of conductive stems did not influence fruit production in mini tomatoes (g.plant $\left.{ }^{-1}\right)$. However, a greater number of stems resulted in a greater fruit number per plant. Plants with 3 and 4 stems produced fruits with a smaller diameter and lower average weight. An increase in the number of stems resulted in higher lycopene, TA, and reducing sugars levels in the fruit.

\section{REFERENCES}

Abrahão, C., Villas Boas, R. L. and Bull, L. T. (2014). Relação K:Ca:Mg na solução nutritiva para a produção de minitomate cultivado em substrato. Irriga, 19, 214-224. http://dx.doi. org/10.15809/irriga.2014v19n2p214.

Bernardi, A. C. C., Werneck, C. G., Haim, P. G., Botrel, N., Oiano Neto, J., Monte, M. B. M. and Verruma-Bernardi, M. R. (2007). Produção e qualidade de frutos de tomateiro cultivado em substrato com zeólita. Horticultura Brasileira, 25, 306-311. http://dx.doi.org/10.1590/S0102-05362007000200035.
Camargos, M. I., Fontes, P. C. R., Cardoso, A. A. and Carnicelli, J. H. A. A. (2000). Produção de tomate longa vida em estufa, influenciada por espaçamento e número de rácimos por planta. Horticultura Brasileira, 18, 563-564.

Carvalho, L. A. and Tessarioli Neto, J. (2005). Produtividade de tomate em ambiente protegido, em função do espaçamento e número de ramos por planta. Horticultura Brasileira, 23, 986989. http://dx.doi.org/10.1590/S0102-05362005000400025. 
Casa, J. and Evangelista, R. M. (2009). Influência das épocas de colheita na qualidade de tomate cultivado em sistemas alternativos. Semina: Ciências Agrárias, 30, 1101-1108.

Charlo, H. C. O., Souza, S. C., Castoldi, R. and Braz, L. T. (2009). Desempenho e qualidade de frutos de tomateiro em cultivo protegido com diferentes números de hastes. Horticultura Brasileira, 27, 144-149. http://dx.doi.org/10.1590/ S0102-05362009000200004.

Chitarra, M. I. F. and Chitarra, A. B. (2005). Pós-colheita de frutas e hortaliças: fisiologia e manuseio. Lavras: Editora da UFLA.

Cunha, A. R. and Martins, D. (2009). Classificação climática para os municípios de Botucatu e São Manuel, SP. Irriga, 14, 1-11. http://dx.doi.org/10.15809/irriga.2009v14n1p01.

Feng, W., Chen, J., Zheng, X. and Liu, Q. (2011). Thyme oil to control Alternaria alternata in vitro and in vivo as fumigant and contact treatments. Food Control, 22, 78-81. http://dx.doi. org/10.1016/j.foodcont.2010.05.010.

Ferreira, D. F. (2011). Sisvar: sistema de análise de variância. Versão 5.3. Lavras: UFLA.

Ferreira, S. M. R., Quadros, D. A., Karkle, E. N. L., Lima, J. J., Tullio, L. T. and Freitas, R. J. S. (2010). Qualidade pós-colheita do tomate de mesa convencional e orgânico. Ciência e Tecnologia de Alimentos, 30, 858-864. http://dx.doi.org/10.1590/ S0101-20612010000400004.

Fontes, P. C. R., Loures, J. L., Galvão, J. C., Cardoso, A. A. and Mantovani, E. C. (2004). Produção e qualidade do tomate produzido em substrato, no campo e em ambiente protegido. Horticultura Brasileira, 22, 614-619. http://dx.doi. org/10.1590/S0102-05362004000300023.

Hanson, P. M., Yang, R., Wu, J., Chen, J., Ledesma, D. and Tsou, S. C. S. (2004). Variation for antioxidant activity and antioxidants in tomato. Journal of the American Society for Horticultural Science, 129, 704-711.

Higuti, A. R. O., Godoy, A. R., Salata, A. C. and Cardoso, A. I. I. (2010). Produção de tomate em função da "vibração" das plantas. Bragantia, 69, 87-92. http://dx.doi.org/10.1590/ S0006-87052010000100012.

Keillor, G. (2008). Plant characteristics and physiology. In J. B. Jones, Tomato plant culture: in the field, greenhouse, and home garden (p. 55-78). Boca Raton: CRC Press.
Marim, B. G., Silva, D. J. H., Guimarães, M. A. and Belfort, G. (2005). Sistemas de tutoramento e condução do tomateiro visando produção de frutos para consumo in natura. Horticultura Brasileira, 23, 951-955. http://dx.doi.org/10.1590/ s0102-05362005000400018.

Matos, E. S., Shirahige, F. H. and Melo, P. C. T. (2012). Desempenho de híbridos de tomate de crescimento indeterminado em função de sistemas de condução de plantas. Horticultura Brasileira, 30 , 240-245. http://dx.doi.org/10.1590/S0102-05362012000200010.

Ministério da Agricultura, Pecuária e Abastecimento (2007). Método de Tillmans modificado; [accessed 2014 Oct 14]. http://www.agricultura.gov.br/

Ministério da Saúde (2005). Métodos físico-químicos para análise de alimentos. Agência Nacional de Vigilância Sanitária. Ministério da Saúde. Brasília: Ministério da Saúde.

Mueller, S. and Wamser, A. F. (2009). Combinação da altura de desponte e do espaçamento entre plantas de tomate. Horticultura Brasileira, 27, 64-69. http://dx.doi.org/10.1590/ s0102-05362009000100013.

Nagata, M. and Yamashita, I. (1992). Simple method for simultaneous determination of chlorophyll and carotenoids in tomato fruit. Nippon Shokuhin Kogyo Gakkaishi, 39, 925928. http://doi.org/10.3136/nskkk1962.39.925.

Nelson, N. (1944). A photometric adaptation of the Somogyi method for determination of glucose. Journal of Biological Chemistry, 153, 375-380.

Santos Júnior, A. M., Maluf, W. R., Faria, M. V., Andrade Júnior, V. C., Nascimento, I. R., Benites, F. R. G. and Gomes, L. A. A. (2005). Produção, qualidade e conservação de tomates heterozigotos nos locos alcobaça, nonripening e ripening inhibitor. Pesquisa Agropecuária Brasileira, 40, 1203-1210. http://dx.doi.org/10.1590/S0100-204X2005001200007.

Seymour, G. B., Taylor J. E. and Tucker G. A. (1993). Biochemistry of fruit ripening. London: Chapman \& Hall.

Silva, E. C., Maciel, G. M., Alvarenga, P. P. M. and Paula, A. C. C. F. F. (2011). Teores de -caroteno e licopeno em função das doses de fósforo e potássio em frutos de diferentes genótipos de tomateiro industrial. Bioscience Journal, 27, 247-252.

Souza, J. L. and Resende, P. (2014). Manual de horticultura orgânica. 3. ed. Viçosa: Aprenda Fácil Editora. 
Takahashi, K. and Cardoso, A. I. I. (2015). Produção e qualidade de mini tomate em sistema orgânico com dois tipos de condução de hastes e poda apical. Horticultura Brasileira, 33, 515-520. http://dx.doi.org/10.1590/S0102-053620150000400018.

Wien, H. C. (1997). The physiology of vegetable crops. 2. ed. New York: Labi Publishing.
Willer, H. (2010). Organic agriculture worldwide: the main results of the FiBL-IFOAM Survey; [accessed 2016 Jul 17]. http://www.ifoam.org

Wills, R. B. H., Lee, T. H., Graham, D., McGrasson, W. B. and Hall E. G. (1982). Postharvest: an introduction to the physiology and handling of fruit and vegetables. Sydney: New South Wales University Press. 